\title{
Research on Social Management System of Exiting from Land by the New Generation of Migrant Workers
}

\author{
Haixin $\mathrm{Liu}^{1}$, Yixin $\mathrm{GaO}^{1}$ \\ ${ }^{1}$ Ideological and Political Education Department, Chongqing University of Technology, Chongqing, \\ 400054, China
}

Keywords: New generation of migrant workers. Land. Social management system

\begin{abstract}
Although the new generation of migrant workers have a high willingness of citizenization, they still have a strong affection to land, it is the premise to realize the citizenization of the new generation of migrant workers to solve their land exiting problems. By starting from the analysis on the relation between the new generation of migrant workers with the land, the author proposes some opinions on the perfection of social management system for exiting from land by the new generation of migrant workers on the basis of existing problems and cause analysis in the exiting from land by the new generation of migrant workers.
\end{abstract}

\section{Introduction}

With the continuous acceleration of industrialization and urbanization in China, the collective land of a lot of farmers has been expropriated to become urban or industrial land, so as to provide space for the development of urbanization and industrialization. The existing from land by the new generation of migrant workers has become a problem urgently to be solved among industrialization, urbanization and the citizenization of new generation of migrant workers.

\section{Analysis on the current situation of relation between the new generation of migrant workers and land}

The new generation of migrant workers have a high willingness of citizenization, but still have a continuous affection to land

The new generation of migrant workers have a strong willingness of citizenization, according to the investigation of Research Group of Development Research Center of the State Council in 2010, among the new generation of migrant workers, 36.5\% aged from 16 to 25 and $28.9 \%$ aged from 36 to 30 hope to live in the cities above prefecture level. It can be seen clearly that the new generation of migrant workers have a willingness of citizenization higher than other age groups. Only 6.4\% aged 16 to 25 and $9.6 \%$ aged from 26 to 30 select to return to the rural areas, both lower than other age groups, which reflects that the new generation of migrant workers have a high willingness of citizenization from a side.

Table 1. Places where migrant workers hope to live, in \%

\begin{tabular}{|l|l|l|l|l|l|l|l|}
\hline Age & $\begin{array}{l}\text { Municipalities } \\
\text { directly under the } \\
\text { central government }\end{array}$ & $\begin{array}{l}\text { Provincial capital } \\
\text { or sub-provincial } \\
\text { city }\end{array}$ & $\begin{array}{l}\text { Prefecture-level } \\
\text { city }\end{array}$ & $\begin{array}{l}\text { County-level } \\
\text { city }\end{array}$ & $\begin{array}{l}\text { County } \\
\text { or small } \\
\text { town }\end{array}$ & $\begin{array}{l}\text { Rural } \\
\text { area }\end{array}$ & $\begin{array}{l}\text { Any } \\
\text { place } \\
\text { in a } \\
\text { city }\end{array}$ \\
\hline $16-25$ & 16.8 & 11.1 & 8.6 & 8.2 & 17.0 & 6.4 & 7.0 \\
\hline $26-30$ & 14.5 & 7.4 & 7.0 & 9.0 & 15.4 & 9.6 & 7.5 \\
\hline $31-40$ & 11.7 & 6.8 & 5.3 & 8.8 & 17.6 & 10.2 & 9.0 \\
\hline $41-50$ & 12.5 & 9.8 & 3.5 & 7.2 & 14.6 & 11.4 & 10.6 \\
\hline $\begin{array}{l}\text { Above } \\
50\end{array}$ & 17.6 & 8.8 & 1.5 & 2.9 & 8.8 & 23.5 & 10.3 \\
\hline
\end{tabular}

Data source: investigation data of the Research Group of the Development Research Center of State Council on migrant workers in 2010 
Although the new generation of migrant workers have a high willingness of citizenization, they still have a continuous affection to land. A majority of the new generation of migrant workers hope to further retain the contracted land and homestead. As sown in Tables 2 and 3, among the new generation of migrant workers, $80.2 \%$ aged from 16 to 25 and $76.1 \%$ aged from 36 to 30 hope to retain the contracted land, and up to $69.4 \%$ and $68.68 \%$ aged $16-25$ hope to retain the homestead and real estate. It can be seen that the new generation of migrant workers have a lower proportion than the old generation of migrant workers in retaining the contracted land, homestead and real estate in the rural areas, which also reflects that the new generation of migrant workers have a high willingness of citizenization from a side.

Table 2. Willingness of migrant workers to dispose of contracted after living in city, in \%

\begin{tabular}{|l|l|l|l|l|l|}
\hline Age & $\begin{array}{l}\text { Retain contracted } \\
\text { land, } \\
\text { self-cultivation }\end{array}$ & $\begin{array}{l}\text { Retained } \\
\text { contracted land, } \\
\text { paid circulation }\end{array}$ & $\begin{array}{l}\text { Benefit-sharing } \\
\text { compensation }\end{array}$ & $\begin{array}{l}\text { Grant urban } \\
\text { household, } \\
\text { waive free of } \\
\text { charge }\end{array}$ & $\begin{array}{l}\text { Grant urban } \\
\text { household, paid } \\
\text { waive }\end{array}$ \\
\hline $16-25$ & 50.9 & 29.3 & 9.4 & 2.2 & 8.2 \\
\hline $26-30$ & 45.1 & 31.0 & 14.2 & 2.7 & 7.1 \\
\hline $31-40$ & 52.8 & 27.2 & 11.3 & 3.1 & 5.5 \\
\hline $41-50$ & 49.7 & 29.1 & 10.3 & 4.1 & 6.8 \\
\hline Above 50 & 48.2 & 33.9 & 5.4 & 7.1 & 5.4 \\
\hline
\end{tabular}

Data source: investigation data of the Research Group of the Development Research Center of State Council on migrant workers in 2010

Table 3. Willingness of migrant workers to dispose of homestead after living in city, in \%

\begin{tabular}{|l|l|l|l|l|}
\hline Age & $\begin{array}{l}\text { Retain the rural homestead } \\
\text { and real estate for further use }\end{array}$ & $\begin{array}{l}\text { Paid } \\
\text { circulatio } \\
\mathrm{n}\end{array}$ & $\begin{array}{l}\text { Grant urban household, } \\
\text { paid waive }\end{array}$ & $\begin{array}{l}\text { Replace the } \\
\text { urban housing }\end{array}$ \\
\hline $16-25$ & 69.4 & 13.4 & 5.0 & 12.2 \\
\hline $26-30$ & 68.8 & 15.1 & 5.4 & 10.7 \\
\hline $31-40$ & 71.0 & 10.6 & 5.0 & 13.4 \\
\hline $41-50$ & 75.5 & 9.1 & 3.0 & 12.5 \\
\hline Above 50 & 75.5 & 13.2 & 3.8 & 7.5 \\
\hline
\end{tabular}

Data source: investigation data of the Research Group of the Development Research Center of State Council on migrant workers in 2010

Importance to perfect the social management system of exiting from land by the new generation of workers.

The perfection of social management system of exiting from land by the new generation of migrant workers is the premise for the new generation of migrant workers to sever the relation between land and guarantee the smooth realization of citizenization. The new migrant workers' smooth existing from land provides development spaces and motive powers for the coordinative development of industrialization and urbanization and helps to disposes of the use of land, reasonably distribute the benefit brought by land, enhance the material basis for the citizenization of new generation of migrant workers, improve their citizenization stability and promote the progress of citizenization of new generation of migrant workers effectively. Solving this problem well is significant to promote the stable progress of the three.

\section{Problems exiting in social management system of exiting from land by the new generation of migrant workers}

The exiting from land has become a difficulty and key point in the citizenization process of the new generation of migrant workers. At present, China is continuously accelerating the progress of industrialization and urbanization, and land problem has become an important factor to trigger the contradiction between farmers and the government and influence the social harmony and stability. 


\section{Hysteresis quality of improving compensation standard for collective land of new generation of migrant workers}

The present land expropriation system of China was basically formed before the reform and opening up. Currently, the non-adaptation in the land expropriation is increasingly manifested, and the social management system for exiting from land by the new generation of migrant workers does not follow the pace of times. The expropriation system of China for the collective land of farmers currently still complies wit the land price system in the times of planned economy, with compensation standard still determined by the government, but not by the marker. The land expropriation compensation standard of China is generally low and mandatory, and great amount of land benefit is taken from the farmers, causing that the new generation of migrant workers have fewer properties distributed in land expropriation, therefore, it is required to improve the compensation standard for land expropriation of collective land of farmers.

Incompleteness in land expropriation compensation system for collective land of new generation of migrant workers

So far, the state has not unveiled a regulation aimed at the compensation standard for land expropriation yet, and the new generation of migrant workers are lack of system guarantee with a high applicability in the land exiting. The Regulations on Housing Expropriation and Compensation in State-owned Land unveiled in 2011 did not specify the expropriation of collective land. Although relevant departments are making great efforts to modify the specifications on collective land expropriation and compensation in the land management law, the new generation of migrant workers are lack of system guarantee in land exiting, causing that they are in the disadvantageous position in the distribution of land property income.

\section{Analysis on reason for problems existing in social management system of exiting from land by new generation of migrant workers}

The social management system for land exiting is not inclined to the interest of new generation of migrant workers

The social management system for land exiting is not inclined to the interest of migrant workers, mainly reflected in the following: the current land management law of China specifies that the land can be expropriated and subject to compensation, but the compensation standard is low, with enforceability in various places. As the new generation of migrant workers are at the bottom of the profit distribution, they are even expelled from the seat of profit distributors. The land property land in China is vague, the state controls the land, farmers are the supplier of land, but they cannot control the willingness to expropriate the land, the supplier and demander of land cannot carry out direct transaction, and the state masters the whole process. The land value is seriously underestimated, and the interest is not inclined to the migrant workers. Empirical research has shown that the price ration of land expropriation, land transfer and market transaction in the developed areas is about 1:10:50. If social management system for the exiting from land by the new generation of migrant workers does not take into account of the reasonable evaluation of market factors, and the interest is not inclined to the new generation of migrant workers, the new generation of migrant workers will become the biggest interest loser in land exiting.

Social management system for exiting from land does not take into account of the difference of willingness of new generation of migrant workers to dispose of land

The willingness of new generation of migrant workers to land disposal is of varieties classifications, some hope to retain the land, some hope to realize paid circulation and some are willing to replace the urban household with land. Although there is much willingness of new generation of migrant workers in land disposal, the current social management system of China for land exiting does not take into account of the difference of willingness of new generation of migrant works, and many rigid specifications in the social management system for land exiting are not actively promoted and even hinder the new generation of migrant workers' exiting from land and prevent their citizenization process. In some places, the new generation of migrant workers are 
changed to citizens rigidly and their land are transformed into social security mandatorily. In many places, the exiting from land by new generation of migrant workers is taken as an important means to improve the ratio of urbanization, without fully considering the quality of urbanization and the requirements for the citizenization of new generation of migrant workers.

\section{Design of social management system for exiting from land by new generation of migrant workers}

\section{Put the new generation of migrant workers and improve the willingness of exiting from land by the new generation of migrant workers}

Many new generation of migrant workers hope that the social management system for exiting from land can fully take into account of their interest in land exiting. So relevant departments should take the maintenance of the interest of new generation of migrant workers as the root. In the central meeting on rural economic worker in 2012, prime Wen Jiabao proposed to improve the distribution proportion of farmers in land value adding. The report of the 18th National Congress of the CPC pointed out the reform of land system and improving of distribution proportion of farmers in land value adding. The third Plenary Session of the 18th National Congress of CPC reemphasized the endowment of more property right to farmers, reflecting the respect to property right of farmers and beneficial to maintain the legal land interest of farmers. In the central meeting on urbanization work in 2012, it was proposed to promote the urbanization by putting people first. These policies provide support for the perfection of social management system for exiting from land by the new generation of migrant workers. By putting the new generation of migrant workers first and improving the distribution proportion of new generation of migrant workers in land value adding can relieve the new generation of migrant workers' pressure of cost bearing in citizenization.

Improve the willingness of new generation of migrant workers to exit from land. Most of the new generation of migrant workers are still unwilling to waive the land use right because their employment system and social security system in the cities have not been perfected, and they take land as the last guarantee for their work and life. Therefore, under this background, it is required to dilute the affection of new generation of migrant workers to land in thought, do the ideological work of new generation of migrant workers in exiting from land. Objectively, the new generation of migrant workers cannot cultivate land, and psychologically, they are unwilling to return to the rural areas for land cultivation. We should accurately master the psychological state of the new generation of migrant workers, make the best use of the circumstance, guide and ensure the new generation of migrant workers to dilute the relying on land. Second, relevant government departments should gradually perfect the urban employment and social security system acceptable to the new generation of migrant workers and make promise to the new generation of migrant workers and eliminate the psychological doubt of new generation of migrant workers in work and life after exiting from land, making them really accept the exiting from land psychologically.

Innovate and perfect various land circulation systems, making the new generation of migrant workers have capital before entering the city

The new generation of migrant workers should obtain reasonable compensation if they exit from land, because some of the their citizenization cost should be borne by themselves; if the income obtained from land existing is low, the capital of them will be thinned, aggravating the difficulty of their citizenization. To solve this problem, it is required to innovate the land circulation system and explore many land circulation methods, making the new generation of migrant workers obtain the maximum benefit in land acquisition. At present, actively exploration has been made in China in this aspect and outstanding achievements have been made. The citizenization of new generation of migrant workers can be classified into household register citizenization and permanent residence citizenization. Therefore, when perfecting the social management system for existing from land by the new generation of migrant workers, it is required to fully take into account of the two conditions, explore many land circulation systems and explore many land value adding methods. In some places, land is replaced with social security and buildings, such means play an important role in promoting 
the household register citizenization and near citizenization of the new generation of migrant workers. For the new generation of migrant workers working outside, these means limit their realization of citizenization, so in the social management system for exiting from land, it is required to fully take into account of their willingness difference. And this require the governments of the household register and permanent place make great efforts to cooperate, innovate the land circulation system and explore many land circulation methods to meet multiple demands of the new generation of migrant workers for land, make the new generation of migrant works obtain the maximum income in land circulation, enhance their basis for citizenization, so as to provide system guarantee for the new generation of migrant workers’ smooth exiting from land and realize their citizenization.

\section{References}

[1] Research Group of the Development Research Center of State Council, System Innovation and Top Design of Citizenization of Migrant Workers [M] Beijing: China Development Press, 2011 (124-126)

[2] Research Group of the Development Research Center of State Council, System Innovation and Top Design of Citizenization of Migrant Workers [M] Beijing: China Development Press, 2011 (87-89)

[3] Li Yining, Far-reaching Significance of Changing Urban and Rural Dural Structure, China Economic \& Trade Herald [J], 2004 (3)

[4] Speech of Wen Jiabao in central meeting on rural work, People’s Network [EB/PL]

http://finance.people.com.cn/GB/16734519.html.

[5] Hu Jintao, Make Progress Firmly Along the Road of Socialism with Chinese Characteristics and Strive to Build a Moderately Prosperous Society: Report in the 18th National Congress of CPC [R], Beijing: People’s Publishing House, 2012

[6] Xi Jinping, Decision of the CPC Central Committee on Several Major Issues on Deepening Reform Comprehensively, portal website of the central government[EB/OL]

http://www.gov.cn/jrzg/2013-11/15/content_2528179.htm.

[7] Important speech of Xi Jinping in central meeting on urbanization work, Xinhuanet [EB/OL] http://news.xinhuanet.com/politics/2013-12/14/c_125859827.htm.

[8] Huang Linzhi, Discussion on Main Obstacles and System Innovation of Citizenization of New Generation of Migrant Workers [D], Xiangtan University, 2012 